\title{
Effectiveness of short-term knowledge communication on Baltic Sea marine genetic biodiversity to public managers
}

\author{
Carina Lundmark $^{1} \cdot$ Klas Andersson $^{2} \cdot$ Annica Sandström $^{1} \cdot$ Linda Laikre $^{3}$
}

Received: 6 July 2016/ Accepted: 3 November 2016/Published online: 17 November 2016

(c) The Author(s) 2016. This article is published with open access at Springerlink.com

\begin{abstract}
The aim of this study is to assess the impact of two forms of short-term knowledge communication-lectures and group deliberations-on public managers' policy beliefs regarding genetic biodiversity in the Baltic Sea. Genetic biodiversity is a key component of biological variation, but despite scientific knowledge and far-reaching political goals, genetic biodiversity remains neglected in marine management. Previous research highlights lack of knowledge among managers as one explanation to the implementation deficit. This multidisciplinary study builds on the identified need for an improved knowledge transfer between science and ongoing management. A basic knowledge package on genetic biodiversity in the Baltic Sea was presented as either a lecture or a deliberative group
\end{abstract}

Editor: Helmut Haberl.

Electronic supplementary material The online version of this article (doi:10.1007/s10113-016-1077-1) contains supplementary material, which is available to authorized users.

Carina Lundmark

carina.lundmark@1tu.se

Klas Andersson

klas.andersson@gu.se

Annica Sandström

annica.sandstrom@1tu.se

Linda Laikre

linda.laikre@popgen.su.se

1 Department of Business Administration, Technology and Social Sciences, Luleå University of Technology,

97187 Luleå, Sweden

2 Department of Education and Special Education, University of Gothenburg, 40530 Gothenburg, Sweden

3 Department of Zoology, Stockholm University, 10691 Stockholm, Sweden discussion to two separate samples of public managers who are involved in Baltic Sea and other biodiversity management at the regional level in Sweden. The empirical findings show that the communicated information has an impact on the public managers' beliefs on genetic biodiversity of the Baltic Sea. Lectures seem more efficient to transfer knowledge on this theme. Those who received information through a lecture strengthen their confidence in area protection as a management tool to conserve genetic diversity. They were also more convinced of the obligation of authorities at national and regional level to take on larger responsibility for genetic conservation than those managers who participated in a deliberative discussion.

Keywords Baltic Sea - Genetic biodiversity $\cdot$ Marine management $\cdot$ Marine protected area $\cdot$ Knowledge communication · Deliberation

\section{Introduction}

Genetic biodiversity is an essential component of biological variation widely recognized in international agreements, most notably in the convention on biological diversity (CBD 1992; www.cbd.int) including in its strategic plan for biodiversity 2011-2020 with the Aichi Biodiversity Targets (COP10 Decision X/2, 2010). The CBD and similar international commitments such as the European Union (EU) Habitats Directive (92/43/EEC) have been incorporated into national and regional policy. However, previous research shows gaps between political objectives and ongoing implementation; in comparison with other levels of biodiversity, genetic biodiversity lags behind (Laikre 2010; Sandström 2010). Similarly, practical management of natural biological resources is often not 
adaptive in taking scientific data and knowledge on genetic biodiversity into account (Laikre et al. 2005; Sandström 2011; Sevä 2013).

Genetic biodiversity is crucial for a species' potential to adapt to a changing environment, and in some environments, such biodiversity is anticipated to be of particular importance (Laikre et al. 2008). The evolutionary young Baltic Sea with its brackish water is recognized as one such sensitive area where genetic biodiversity in single species might compensate for relatively low species diversity (Johannesson et al. 2011). Ongoing environmental changes in the Baltic Sea, e.g. pollution, large-scale fishing, introduction of alien species and effects related to climate change, increase the importance of genetic biodiversity as a foundation for resilience (e.g. Meier 2006; Neumann 2010). Sustaining genetic biodiversity in the Baltic Sea species is expected to increase their chances of long-term survival (e.g. Johannesson et al. 2011).

A recent study of the management of Baltic Sea marine protected areas (MPAs) shows that genetic variation is poorly integrated into the goals, measures and strategies for monitoring expressed in the management plans (Laikre et al. 2016), again demonstrating that in spite of scientific knowledge and far-reaching political goals genetic diversity remains neglected in conservation implementation. Several factors that can explain why genetic biodiversity is largely absent in Baltic Sea MPAs management have been identified, besides lack of knowledge and other resources, also unclear formal policy on how genetic biodiversity should be handled in ongoing marine management. The responsible managers' views of the problem and its solutions, i.e. their policy beliefs, are additional explanatory factors (Sandström et al. 2016). The present multidisciplinary study builds on the identified need for a better knowledge transfer between science and practice. We focus on those low-level public managers who currently work with marine biodiversity protection in the Baltic Sea using Sweden and the Swedish County Administrative Boards as an example to study the impact of different kinds of knowledge communication. The objective is to find out whether knowledge communication has an impact on managers' perceptions of marine genetic biodiversity and whether different forms of knowledge communication vary in effectiveness in this respect.

Previous research on deliberative democratic theory and practice within the field of natural resource management suggests that deliberation-shortly defined as constructive group discussions-can be anticipated to have larger impact than unidirectional communication (e.g. lectures) to increase participants' understanding (Black 2008; Dryzek 2000). The reason for this presupposition is that deliberative talk can increase the participants' understanding of the other actors' experience and points of view (Dryzek and Niemeyer 2006; Smith 2001). Whether shared understanding actually occurs following deliberation is, however, an understudied topic within the research field of natural resource management (Birnbaum et al. 2015; Zachrisson 2010). Studies in this research field typically do not test the merits of different forms of knowledge communication. Rather, such investigation is primarily carried out within the field of educational research where several scholars have demonstrated support for conventional forms of knowledge communication (e.g. traditional lectures) and some have suggested deliberation as ineffective and even superfluous (Scheerens et al. 2007; Sommers 2000). The effects of traditional lectures versus deliberation are, however, not compared.

Here, we combine competences from educational research, political science, and population and conservation genetics to assess the impact of different forms of shortterm knowledge communication-lectures and group deliberations-on low-level, public managers' policy beliefs in regard to genetic biodiversity in the marine environment. Specifically, we (1) develop a basic knowledge package on genetic biodiversity with a focus on the Baltic Sea that can be presented as a lecture or as a deliberation exercise, (2) present this material to separate samples of public managers involved in Baltic Sea and other regional biodiversity management and (3) assess quantitatively the managers' perception of genetic biodiversity before and after the communication effort. To our knowledge, this is the first time this type of study is carried out with respect to natural resource management and conservation biology. The questions we address based on this approach are:

A: Does the knowledge communication affect public managers' perceptions of genetic biodiversity of the Baltic Sea?

B: Are there differences between the two methods of knowledge communication with respect to efficiency in affecting the policy beliefs of public managers?

\section{Theory}

Supported by deliberative democratic theory (e.g. Dryzek 2000; Smith 2001; Dryzek and Niemeyer 2006), a specific kind of dialogue — deliberation — among parties/individuals concerned with a particular topic is widely proposed and used in natural resource management (Birnbaum et al. 2015; Parkins and Mitchell 2005). The presumed capacity of deliberation to create joint problem understandings and, thus, legitimacy explains its popularity when designing management settings for contested policy areas such as water management (e.g. Parés et al. 2015) and wildlife management (e.g. Lundmark and Matti 2015). 
The transformative power of deliberation depends on a number of criteria, including that the information provided during the discussion is accurate and relevant to the participator. The information must also be carefully structured so that all participants can share and sincerely weigh all arguments (Fishkin 1995; Gutmann and Thompson 2004; Luskin et al. 2000). Proponents of deliberation claim that people are in a position to learn more successful if they, along with others in an open, unpretentious conversation, listen to each other's arguments. Participants are expected to increase their understanding both of the topic of concern and of the views and standpoints of the other participants (Fishkin and Farrar 2005; Gutmann 1999).

Several theorists argue that deliberative conversations should be used more in different kinds of learning situations to enhance people's knowledge and democratic skills (Gutmann 1999; Fishkin and Farrar 2005). It has also been argued, however, that deliberative communication is both ineffective and even unnecessary (Murphy 2004). In higher education, for instance, the model of conventional teaching-oriented towards teacher-centred teaching, using communication between the teacher and a group of students-still dominates the scene. Particularly an approach of initiating questions, letting the class respond and evaluating the answers [so-called initiate-response-evaluate (IRE) sequences], is often used. Proponents of this conventional knowledge communication argue that it is much more effective than group deliberation because the teacher, who is most knowledgeable, is the key communicator in the classroom (Sommers 2000; Scheerens et al. 2007). Several studies show that teacher-driven dialogue is very effective for student achievement in higher education (Caldwell 2007; Dufresne et al. 1996; Wenk et al. 1997).

In the present study, we test lecture and deliberative group discussion in the context of marine biodiversity management to see which model, if any, has the capacity to increase the awareness of genetic biodiversity and the perceived importance of considering genetics in management among low-level public managers in Sweden.

Thus, the dependent factor in our study concerns the outcome of the different forms of communication that we test, in terms of altered policy beliefs. Beliefs are multifaceted concepts used in several disciplines. We rely on the rationale of belief systems proposed within the advocacy coalition framework (ACF), according to which systems of beliefs guide the individual, or groups of individuals, both in their perception of risk and when making priorities regarding political trade-offs (Weible and Sabatier 2005, 2009).

The components of an individual's belief system are hierarchically ordered, with the most stable values at the very core (Fig. 1). These deep core values concern basic ontological views, such as views on freedom, authority and social order (Weible and Sabatier 2009). Policy core beliefs, on the other hand, are linked to a particular policy subsystem, consisting of an issue, a geographic area and stakeholders (Weible and Sabatier 2005, 2009). Policy core beliefs can both be empirical and normative. Normative policy core beliefs entail welfare priorities that are linked to the subsystem (cf. Sabatier and Jenkins-Smith 1999; Weible and Sabatier 2009), which in our case could imply the fundamental distinction between conservation and exploitation of the marine environment. Empirical policy core beliefs comprise beliefs of causes to the problem, such as loss of genetic biodiversity in Baltic Sea species, its perceived severity and general strategies to deal with the problems, including distribution of responsibility between state and market actors. Following the ACF, empirical policy core beliefs are considered easier to change than the normative ones. Weible and Sabatier (2009) particularly stress the susceptibility of empirical core beliefs to new scientific information, which corresponds well with our test of different methods for knowledge communication.

Finally, secondary aspects constitute the most empirical and easy-to-change component of the belief system, and refer to specific implementation strategies concerning some part of the policy subsystem (Fig. 1; Matti and Sandström 2013). In our case, secondary aspects concern beliefs regarding MPAs as a management tool for maintaining marine genetic biodiversity. Secondary aspects can also embrace views on specific policy proposals, such as measures to prevent the introduction of invasive species in an area. As fundamental and stable beliefs cannot be expected to change due to the short-term communication efforts used in our study, these are not investigated here. Instead, we focus on views that are more open to change following the theoretical framework: empirical policy core beliefs and secondary aspects (Fig. 1).

\section{Materials and methods}

The study explored how two forms of knowledge communication-traditional lecture versus deliberative group discussion-affected the policy beliefs of public managers who work with marine biodiversity protection at Swedish County Administrative Boards (CABs) bordering to the Baltic Sea, i.e. the regional state authority that is assigned responsibility for establishing and managing Swedish MPAs. The logic for focusing on Swedish management was to build on our previous research results (Laikre et al. 2016; Sandström et al. 2016). We have found that Sweden has somewhat stronger wordings on the importance of genetic diversity protection in national policy (such as national biodiversity and action plans following the CBD and EU Directives) than Finland, Estonia and Germany. In comparison, Swedish policy documents also have the most 


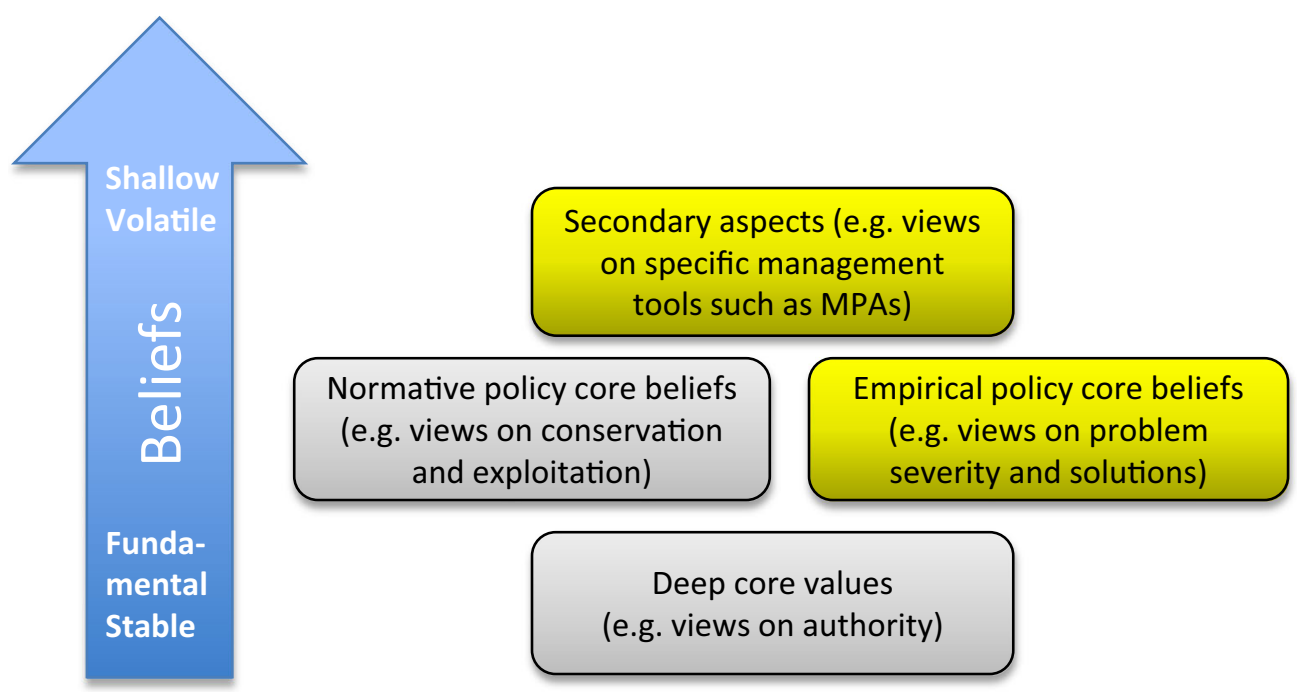

Fig. 1 Components of anindividual's belief system with the components in focus of the present article in yellow

far-reaching intentions for monitoring genetic biodiversity. However, management plans for Baltic Sea MPAs are lacking genetic concerns in all four countries (Laikre et al. 2016). An in-depth study of Swedish and Finnish Baltic Sea MPA management identified lack of knowledge as one of the reasons for why genetic concerns are missing in management plans (Sandström et al. 2016). Here, we want to find out whether knowledge communication can potentially affect empirical policy core beliefs and secondary aspects, that is, shallow and volatile beliefs, and focus on one of our in-depth study countries.

Twelve of Sweden's 21 CABs have Baltic coastline according to the definition used in this study ${ }^{1}$ : Norrbotten, Västerbotten, Västernorrland, Gävleborg, Uppsala, Stockholm, Södermanland, Gotland, Kalmar, Blekinge, Skåne and Östergötland. These CABs were contacted, first to inquire their interest in either a lecture or a group discussion on genetic biodiversity in the Baltic Sea and second to identify those managers who work with MPAs more or less extensively (either HELCOM MPAs and/or Natura 2000 with marine habitats), as well as the number of managers who work with related issues. ${ }^{2}$ Most CABs were interested in participating, and we managed to schedule either lecture

\footnotetext{
${ }^{1}$ We adopted the definition of the Baltic Sea advocated by Johannesson and André (2006).

${ }^{2}$ HELCOM (Baltic Marine Environment Protection Commission) is the governing body of the Convention on the Protection of the Marine Environment of the Baltic Sea Area, commonly known as the Helsinki Convention. The Contracting Parties (Denmark, Estonia, the EU, Finland, Germany, Latvia, Lithuania, Poland, Russia and Sweden) adopt Recommendations to protect the marine environment of the Baltic Sea through intergovernmental collaboration (www. helcom.fi). Natura 2000 is a network of protected areas (terrestrial and marine) within the EU following the Habitats Directive (92/43/EEC) and the Birds Directive (Directive 2009/147/EC).
}

or deliberation in nine of the $12 \mathrm{CABs}$ (Table 1). The reasons for missing three $\mathrm{CABs}$ were: one $\mathrm{CAB}$ declined participation, in one case we did not manage to get in contact with the management, while in a third case we were not able to find a time that suited the $\mathrm{CAB}$ due to other activities.

The number of individuals participating in the study at each CAB varied between 4 and 16 (Table 1). When selecting participants, priority was given to relevance in terms of work tasks and interest in participating, assigning no weight to other background variables such as age, education or gender. Nevertheless, the two groups (deliberation and lectures) turned out homogeneous in terms of these aspects. Most participants were born in the 1960s or 1970s with a mean year of birth of 1969.7 and 1969.9 in the deliberation and lecture group, respectively. The proportion of women in the two groups was 0.47 and 0.59 (i.e. within the span of $40 / 60 \%$ which is commonly considered gender equal). With respect to education, all participants had university education, primarily in biology (the frequency of biologists was around 0.85 in both groups), and the proportion of individuals holding a $\mathrm{PhD}$ was $28 \%$ in the deliberation group and $14 \%$ in the lecture group. In none of these cases was there a statistically significant difference between the two groups. The participants commonly worked with nature conservation including area protection, environmental assessment, water and fishing. In a few cases, some participants represented other fields such as rural development, economic growth and infrastructure, yet with some involvement in MPA management.

Based on the number of individuals who were interested in participating at each respective $\mathrm{CAB}$, we chose the allocation of either deliberation or lecture. We tried to get large groups for the lectures while deliberation exercises 
Table 1 Number of County Administrative Boards (CABs) and the number of participants at each activity included in the study (in total 9 $\mathrm{CABs}$ and 76 individual managers)

\begin{tabular}{llc}
\hline CAB & Knowledge communication & Number of participants \\
\hline A & Deliberation & 4 \\
B & Deliberation & 8 \\
C & Deliberation & 9 \\
D & Deliberation & 6 \\
E & Deliberation & 5 \\
Total no participants for deliberation & 32 \\
F & Lecture & 12 \\
G & Lecture & 6 \\
H & Lecture & 10 \\
I & Lecture & 16 \\
Total no participants for lecture & 44 \\
\hline
\end{tabular}

One of the participants at CAB C participated over Skype due to working at other location at the time of the activity

were conducted in the somewhat smaller environments, to optimize the functioning of the deliberative process, which is widely recognized to work best in smaller groups (Fishkin 1995). In some cases, the result became the opposite (lecture for a small group) due to sickness leave or other scheduled activities that we were unaware of when setting the dates, also we tried to get approximately equal total numbers of participants for the two types of knowledge communications (Table 1).

In total, 76 managers participated in the study; sample size for deliberation was 44 and for lecture 32. The knowledge communications were held at the respective $\mathrm{CAB}$. Deliberations were conducted during April-May 2015, while lectures were held during June-October the same year.

To be able to identify potential effects of the two forms of knowledge communications on the managers' beliefs, the substantive part of the information included in the lecture and the group deliberation was identical, yet presented entirely differently. Both forms of knowledge communication were held by a professor in population genetics and encompassed the following topics: the meaning of genetic biodiversity, why it is important based on the function it fulfils, typical threats, exemplifications of the state of knowledge with regard to the genetic biodiversity of species in the Baltic Sea and, finally, how it can be taken into account in management, for instance through different forms of area protection. Power-point slides were used in both settings. While the lecture was structured around a large number of slides (about 30) and lasted for 30-45 min, about a third of the pictures were showed during the group deliberation (in no predetermined order) and the participants were invited to discuss the themes, based on predefined questions, and to share their own experiences, for instance on how genetic biodiversity can be considered in ongoing management. ${ }^{3}$ At the introduction of the knowledge communication, the research project was briefly introduced and we told the participants that we would hand out a short survey before and after the knowledge communication. Participation in the survey was voluntary. The deliberations lasted about $2 \mathrm{~h}$. One or two researchers observed the activity, both deliberation and lecture. While the entire deliberation was recorded on tape after consent from the participants, and notes were taken throughout, only the dialogue (questions and comments from the audience) was noted during the lectures.

We used surveys before and after the knowledge communication to evaluate the effects on the participants' beliefs (Supplementary Material Appendix S1). The survey questions were inspired by previous ACF research (c.f. Hysing and Olsson 2008; Matti and Sandström 2013) and were designed to tap participants' views of the problem, its seriousness, distribution of responsibility and brief reflections on strategies to deal with it (Supplementary Material Appendix S2).

The same questions were asked both before and after (except the background questions that were only asked once), and to be able to pair the two surveys, we asked the respondents to write their names on the front pages. They could use an alias if they wished. To be able to refer to the respondents in our analysis, for instance to quote their statements on open survey questions without compromising their anonymity, each one was assigned a letter that signifies the CAB they work at (A-I), and a number (e.g. A:5).

The quantitative statistical analysis of answers to survey questions was performed with the STATA software (www. stata.com). First, we used $t$ tests to confirm that no differences existed between the two groups before the knowledge communication. Second, we tested the mean change among $\mathrm{CAB}$ managers having the same knowledge communication, comparing scores before and after applying paired $t$ tests. Third, we tested whether the mean change differed significantly between the two groups, deliberative and lecture, using unpaired $t$ tests.

\section{Results}

In no case did we find statistically significant differences between the two groups (deliberation vs. lecture) prior to the knowledge communication. The quantitative results are

\footnotetext{
3 To test the knowledge content and the design of the forms of communication, we organized a pilot study in March 2015 involving students at a beginner's course in Conservation Biology at Stockholm University. The test was conducted at an early stage of the course, just after the introduction, to prevent that the students' had already attained knowledge on genetic biodiversity.
} 
Table 2 Summary statistics for answers to survey questions provided by managers participating in either a deliberative discussion or a lecture

\begin{tabular}{|c|c|c|c|c|c|c|c|}
\hline & \multicolumn{3}{|c|}{ Deliberation } & \multicolumn{3}{|c|}{ Lecture } & \multirow{2}{*}{$\begin{array}{l}\text { Difference } \\
\text { Delib-lect }\end{array}$} \\
\hline & $\mathrm{T} 1$ & $\mathrm{~T} 2$ & $\begin{array}{l}\text { Diff bef- } \\
\text { aft }\end{array}$ & $\mathrm{T} 1$ & $\mathrm{~T} 2$ & $\begin{array}{l}\text { Diff bef- } \\
\text { aft }\end{array}$ & \\
\hline To what extent do you think you have knowledge about genetic biodiversity? & 3.75 & 4.66 & $\begin{array}{l}+0.91 * * * * \\
n=32\end{array}$ & 3.80 & 4.61 & $\begin{array}{l}+0.82 * * * * \\
n=44\end{array}$ & $\begin{array}{l}0.09 \\
n=76\end{array}$ \\
\hline $\begin{array}{l}\text { To what extent do you think you have knowledge about the importance of } \\
\text { genetic biodiversity of the Baltic Sea? }\end{array}$ & 3.72 & 4.91 & $\begin{array}{l}+1.19 * * * * \\
n=32\end{array}$ & 3.50 & 5.09 & $\begin{array}{l}+1.59 * * * * \\
n=44\end{array}$ & $\begin{array}{l}0.40 \\
n=76\end{array}$ \\
\hline $\begin{array}{l}\text { To what extent do you think the genetic biodiversity is of importance for the } \\
\text { Baltic Sea? }\end{array}$ & 5.91 & 6.19 & $\begin{array}{l}+0.28 \\
n=32\end{array}$ & 6.09 & 6.41 & $\begin{array}{l}+0.32 * \\
n=43\end{array}$ & $\begin{array}{l}0.04 \\
n=75\end{array}$ \\
\hline $\begin{array}{l}\text { To what extent do you think the genetic biodiversity of the Baltic Sea is } \\
\text { threatened? }\end{array}$ & 5.15 & 5.56 & $\begin{array}{l}+0.41 * * \\
n=32\end{array}$ & 5.44 & 6.02 & $\begin{array}{l}+0.58 * * * * \\
n=43\end{array}$ & $\begin{array}{l}0.17 \\
n=75\end{array}$ \\
\hline $\begin{array}{l}\text { In comparison with other issues, how should the conservation of genetic } \\
\text { biodiversity in the Baltic Sea be prioritized? }\end{array}$ & 4.88 & 5.19 & $\begin{array}{l}+0.31 * \\
n=32\end{array}$ & 4.63 & 5.47 & $\begin{array}{l}+0.84 * * * * \\
n=43\end{array}$ & $\begin{array}{l}0.52 * * \\
n=75\end{array}$ \\
\hline $\begin{array}{l}\text { To what extent should the state/authorities have responsibility for protecting } \\
\text { the genetic biodiversity of the Baltic Sea? }\end{array}$ & 6.57 & 6.63 & $\begin{array}{l}+0.07 \\
n=30\end{array}$ & 6.36 & 6.67 & $\begin{array}{l}+0.31 * * * \\
n=42\end{array}$ & $\begin{array}{l}0.24 * \\
n=72\end{array}$ \\
\hline $\begin{array}{l}\text { To what extent should the regional level (the } \mathrm{CAB} \text { ) have responsibility to } \\
\text { protect the genetic biodiversity of the Baltic Sea? }\end{array}$ & 5.80 & 5.73 & $\begin{array}{l}-0.07 \\
n=30\end{array}$ & 5.62 & 5.98 & $\begin{array}{l}+0.36^{* * *} \\
n=42\end{array}$ & $\begin{array}{l}0.42 * * \\
n=72\end{array}$ \\
\hline $\begin{array}{l}\text { To what extent should municipalities have responsibility to protect the } \\
\text { genetic biodiversity of the Baltic Sea? }\end{array}$ & 4.70 & 4.67 & $\begin{array}{l}-0.03 \\
n=30\end{array}$ & 5.02 & 5.23 & $\begin{array}{l}+0.21 \\
n=42\end{array}$ & $\begin{array}{l}0.24 \\
n=72\end{array}$ \\
\hline $\begin{array}{l}\text { To what extent should market actors have responsibility to protect the } \\
\text { genetic biodiversity of the Baltic Sea? }\end{array}$ & 4.74 & 4.58 & $\begin{array}{l}-0.16 \\
n=31\end{array}$ & 4.78 & 5.00 & $\begin{array}{l}+0.22 \\
n=41\end{array}$ & $\begin{array}{l}0.38 * \\
n=72\end{array}$ \\
\hline $\begin{array}{l}\text { How do you assess the effectiveness of regulation as a control instrument to } \\
\text { protect the genetic biodiversity of the Baltic Sea? }\end{array}$ & 5.48 & 5.96 & $\begin{array}{l}+0.48 * * * \\
n=31\end{array}$ & 5.41 & 5.90 & $\begin{array}{l}+0.49 * * * * \\
n=41\end{array}$ & $\begin{array}{l}0.01 \\
n=72\end{array}$ \\
\hline $\begin{array}{l}\text { How do you assess the effectiveness of information as a control instrument } \\
\text { to protect the genetic biodiversity of the Baltic Sea? }\end{array}$ & 4.26 & 4.84 & $\begin{array}{l}+0.58 * * * * \\
n=31\end{array}$ & 4.37 & 5.24 & $\begin{array}{l}+0.88 * * * * \\
n=41\end{array}$ & $\begin{array}{l}0.30 \\
n=72\end{array}$ \\
\hline $\begin{array}{l}\text { Are protected areas an effective management tool to maintain the genetic } \\
\text { biodiversity of the Baltic Sea? }\end{array}$ & 4.77 & 5.00 & $\begin{array}{l}+0.23 \\
n=31\end{array}$ & 4.57 & 5.25 & $\begin{array}{l}+0.68 * * * * \\
n=44\end{array}$ & $\begin{array}{l}0.46^{*} \\
n=75\end{array}$ \\
\hline
\end{tabular}

The first and second columns (T1 and T2) show the mean, before and after, the deliberative knowledge communication. The third column (Diff bef-aft) shows the average change in the deliberation group (paired $t$ tests were used to test for significances). Corresponding information for the lecture group is shown in the fourth, fifth and sixth columns. The seventh column (difference delib-lect) shows the difference in mean change between the two types of knowledge communication (unpaired $t$ tests were used). The scale in the questions runs from 1 to 7 (e.g. $1=$ not important; low priority, 7 = very important; very high priority)

$* p<0.10 ; * * p<0.05 ; * * * p<0.01 ; * * * *<<0.001$

summarized in Table 2 (additional information in Electronic Supplementary Table S1).

\section{Importance and priority of genetic biodiversity of the Baltic Sea}

Our results indicate that both knowledge communications bring the issue of genetic biodiversity higher up on the managers' agenda, although the lecture has the largest impact on the managers' empirical policy core beliefs. There is a slight increase in the beliefs of the perceived importance of genetic biodiversity for the Baltic Sea. This increase is statistically significant in the lecture group $(p<0.10$; Table 2, row 3), but not for the deliberation group.

Both activities significantly increase the perception of the priority that should be given to genetic biodiversity, but the increase is significantly larger in the lecture group (Table 2, row 5). The managers' self-reported knowledge about genetic diversity and its importance for the Baltic Sea increase significantly in both deliberative and lecture groups (Table 2, rows 1-2).

\section{Perceived threats to genetic biodiversity in the Baltic Sea}

The basic knowledge package we developed for this study explicated the meaning of genetic biodiversity and its importance in the evolutionary young Baltic Sea. Most of the examples, in both the lectures and the group discussions, concerned fish, particularly salmon, which corresponds well with the scientific knowledge base. In response to an open-ended survey question, the most commonly 
mentioned threats to genetic biodiversity were also related to fishing: extensive fishing, selective fishing and restocking activities; 44 of the 76 respondents mentioned activities relating to fishing as a potential threat to genetic diversity. About the same number of such concerns occurs before and after the knowledge communication. We find several individuals from both groups, however, who refined their views on fishing as a threat after the knowledge communication. For instance, D:1 wrote "fishing", "aquaculture" and "shipping" before the deliberative communication and "[s]election by human activities such as fishing, and reduced populations due to exploitation" after the deliberation. Similarly, H:10 simply wrote "overfishing" before the lecture and "Restocking of fish... with breeding from fewer than 50 individuals, selective fishing" after the lecture. Only five individuals, however, explicitly mentioned genes before the communication, while the corresponding number afterwards was eleven (e.g. "genetic impoverishment", "introduction of alien genotypes" or simply "genetic variation"). Most of these answers refer to deliberative communication (four before the knowledge communication and eight after). Thus, our qualitative data indicate a more nuanced stance with regard to threats to genetic biodiversity after the knowledge communication, but only subtle differences between the two forms of communication. This result is backed up by quantitative data.

The managers significantly changed their view concerning the extent to which they consider genetic biodiversity of the Baltic Sea to be under threat after compared to before the knowledge communication, in the sense that both the deliberative and lecture groups find the threat more alarming after the communication (Table 2; row 4). The difference between the groups is not statistically significant.

\section{Distribution of responsibility for genetic biodiversity of the Baltic Sea}

Views regarding responsibility also are key components of empirical policy core beliefs. As shown in Table 2 (rows 6-9), CAB managers who participated in lectures thought that national authorities and CABs should take more responsibility after compared to before the knowledge communication. Managers in the deliberative group did not change their views on this matter. The difference between the groups is statistically significant. With respect to responsibilities of municipalities and market actors, none of the groups change their beliefs to a degree that was significant. However, the change in opposite direction for market actors (decrease in deliberation group and increase in lecture group) was large enough to provide a weak statistical significance (Table 2, line 9).

\section{Strategies to deal with genetic biodiversity of the Baltic Sea}

Table 2 also presents the findings concerning managers' empirical policy core beliefs about how to protect genetic biodiversity of the Baltic Sea (empirical policy core beliefs and secondary aspects, rows 4-5 in Supplementary Material Appendix S2). After the knowledge communication, the lecture group estimated the effectiveness of area protection, as well as the use of regulation and information as tools to maintain genetic biodiversity, higher than before the communication. The deliberative group also expressed an increased confidence in regulation and information but their initial views on protected areas remained unchanged. The difference between the two groups was statistically significant with respect to the secondary aspect of use of MPA as an effective management tool to protect genetic biodiversity. Thus, both the deliberation and the lecture had an impact on policy core beliefs, while the lecture also altered the more shallow secondary aspects.

\section{Discussion}

This study has assessed how two forms of short-term knowledge communication (lecture and group deliberation) affect how public managers at Swedish County Administrative Boards (CABs) perceive genetic biodiversity in the Baltic Sea, the management problem and its solutions. Previous research and practice highlight merits of both forms of communication; deliberative discussion has the capacity to modify the participants' beliefs, while unidirectional communication is time efficient and relatively easy to adapt to different audiences. To our knowledge, our study is the first to quantitatively compare the two methods in a regional biodiversity conservation management context.

Our results show that both forms of knowledge communication have an effect, in the sense that the participants' beliefs on genetic biodiversity of the Baltic Sea change. Despite the short-term perspective in our study, we can see that the communicated information has an impact on the managers' beliefs; it increases their risk perception and alters their views on responsibility and various strategies to address the problems they perceive. The managers' self-reported knowledge on genetic biodiversity and its importance for the Baltic Sea also increases as a consequence of the knowledge communication, as well as the priority given to genetic biodiversity in ongoing marine management.

Our results suggest that lectures are more efficient to transfer knowledge on genetic biodiversity to the managers at Swedish CABs. Thus, beliefs have altered more in the 
lecture group than in the deliberation group. Those who receive information through a lecture strengthen their confidence in area protection as a management tool. The qualitative data, on the other hand (answers to an openended question on the threats to genetic biodiversity of the Baltic Sea), suggest that the deliberative group got a somewhat more refined understanding of genetic biodiversity, as they exchanged facts and experiences. These results might indicate that deliberation is more suitable for addressing more deeply rooted beliefs, while lectures are better suited to target the more volatile secondary aspects. To investigate this further, more data are needed, preferably of a qualitative kind.

One possible explanation to the lack of support for deliberation can be related to the topics addressed. Deliberations enable scrutiny of diverse positions and are primarily used in contested fields of natural resource management, for example wildlife management including large carnivores (Lundmark and Matti 2015) or the use of snowmobiles in a mountain region (Zachrisson 2010). Our audio recordings from the deliberations suggest relatively homogeneous and moderate views among the participants. The arguments are fact based and commonly based on limited personal experience of actually working with genetic biodiversity in practice. For more conflict-laden issues, and participants having a personal stake in the matters discussed, the effect of deliberation might be more pronounced, yet also more challenging.

The participants' state of knowledge is a possible explanation to both their moderate views and the lack of support for deliberation. As some managers participating in our study had little prior knowledge on genetic biodiversity according to self-evaluation (Table 2), the transformative power of deliberation perhaps have not reached its full potential in our study. For instance, results from previous research on deliberative polling show that knowledgeable participants are the ones changing their opinions the most (Luskin et al. 2000, 2002). In future studies, written information material could be handed out prior to the deliberation, to facilitate informed dialogue among the managers.

Another important task for future research is to investigate how stable the alterations are, i.e. whether short-term communication such as the one pursued in this study produces a lasting change in the participants' beliefs and if there are any changes between the two groups in this respect. It could, perhaps, be argued that the smaller belief-change arising from deliberation is different, more substantial and robust, due to the situation in which it emerged (encouraging different perspectives, competing views and argumentation). In our case, it would also be interesting to study the link between policy beliefs and action, e.g. to investigate whether (and how) CAB managers convert their concerns about risks to genetic biodiversity into action and, indeed, whether they continue to place genetic biodiversity high on the agenda in comparison with other pressing concerns.

\section{Conclusions}

We have assessed how two forms of short-term knowledge communication-traditional lecture versus deliberative discussion- affect how managers at Swedish CABs perceive genetic biodiversity in the Baltic Sea, the management problem and its solutions. Our findings show that the communicated information has an impact, in the sense that:

- Both short-term forms of communication (traditional lecture vs. deliberative discussion) stimulate knowledge development and the priority given to genetic biodiversity in the Baltic Sea among the CAB managers.

- The lecture was more efficient than the deliberative discussion in modifying both empirical core beliefs and secondary aspects, but the understanding of the concept of genetic biodiversity appears to have increased more in the deliberative groups.

- The significant changes found between the two forms concerned prioritization of genetic diversity, responsibility and management strategies to protect genetic biodiversity.

This study contributes to an increased understanding of different forms of knowledge communication and contributes to the science-policy interface by formulating a set of practical implications for policy and management.

Acknowledgements We would like to thank our two anonymous reviewers for insightful comments and suggestions. This work resulted from the BONUS BAMBI Project and was supported by BONUS (Art 185), funded jointly by the European Union and the Swedish Research Council Formas (215-2012-1550, AS, LL). Financial support to LL and AS from the Swedish Research Council Formas is also acknowledged.

Open Access This article is distributed under the terms of the Creative Commons Attribution 4.0 International License (http://crea tivecommons.org/licenses/by/4.0/), which permits unrestricted use, distribution, and reproduction in any medium, provided you give appropriate credit to the original author(s) and the source, provide a link to the Creative Commons license, and indicate if changes were made.

\section{References}

Birnbaum S, Bodin Ö, Sandström A (2015) Tracing the sources of legitimacy: the impact of deliberation in participatory natural resource management. Policy Sci 48:1-19. doi:10.1007/s11077015-9230-0

Black J (2008) Constructing and contesting legitimacy and accountability in polycentric regulatory regimes. Regul Gov 2:137-164. doi:10.1111/j.1748-5991.2008.00034.x 
Caldwell JE (2007) Clickers in the large classroom: current research and best-practice tips. Cell Biol Educ 6:9-20. doi:10.1187/cbe. 06-12-0205

CBD (1992) Convention of biological diversity. Rio de Janeiro, 5 June 1992. United Nations Treaty Series 1760: 1-30619. http:// www.cbd.int/convention/text/. Accessed 13 Oct 2015

CBD COP10 Decision X/2 (2010) Strategic plan for biodiversity 2011-2020, including Aichi biodiversity targets. In: The 10th meeting of the conference of the parties, 18-20 Oct 2010, Nagoya. http://www.cbd.int/decision/cop/default.shtml?id= 12268. Accessed 13 Oct 2015

Council Directive 92/43/EEC (1992) The habitats directive. Official Journal of the European Communities, L 206, 22 July 1992. http://eur-lex.europa.eu/legal-content/EN/TXT/?uri=CELEX: 31992L0043. Accessed 14 Oct 2015

Dryzek JS (2000) Deliberative democracy and beyond: liberals, critics, contestations. Oxford University Press, Oxford

Dryzek JS, Niemeyer S (2006) Reconciling pluralism and consensus as political ideals. Am J Polit Sci 50:634-649. doi:10.1111/j. 1540-5907.2006.00206.x

Dufresne RJ, Gerace WJ, Leonard WJ, Mestre JP, Wenk L (1996) Classtalk: a classroom communication system for active learning. J Comput High Educ 7:3-47. doi:10.1007/bf02948592

Fishkin JS, Farrar C (2005) Deliberative polling: from experiment to community resource. In: Gastil J, Levine P (eds) The deliberative democracy handbook. Jossey-Bass, San Francisco, pp 68-79

Fishkin JS, Public Broadcasting Service (1995) The voice of the people: public opinion and democracy. Yale University Press, New Haven

Gutmann A (1999) Democratic education: with a new preface and epilogue. Princeton University Press, Princeton

Gutmann A, Thompson D (2004) Why deliberative democracy?. Princeton University Press, Princeton

Hysing E, Olsson J (2008) Contextualising the advocacy coalition framework: theorising change in Swedish forest policy. Environ Polit 17:730-748. doi:10.1080/09644010802421471

Johannesson K, André C (2006) Life on the margin: genetic isolation and diversity loss in a peripheral marine ecosystem, the Baltic Sea. Mol Ecol 15:2013-2029. doi:10.1111/j.1365-294X.2006. 02919.x

Johannesson K, Smolarz K, Grahn M, André C (2011) The future of Baltic Sea populations: local extinction or evolutionary rescue? Ambio 40:179-190. doi:10.1007/13280-010-0129-x

Laikre L (2010) Genetic diversity is overlooked in international conservation policy implementation. Conserv Genet 11:349-354. doi:10.1007/s10592-009-0037-4

Laikre L, Palm S, Ryman N (2005) Genetic population structure of fishes-implications for coastal zone management. Ambio 34:111-119. doi:10.1579/0044-7447-34.2.111

Laikre L, Larsson LC, Palmé A, Charlier J, Josefsson M, Ryman N (2008) Potentials for monitoring gene level biodiversity: using Sweden as an example. Biodivers Conserv 17:893-910. doi:10. 1007/s10531-008-9335-2

Laikre L, Lundmark C, Jansson E, Wennerström L, Edman M, Sandström A (2016) Lack of recognition of genetic biodiversity: international policy and its implementation in Baltic Sea marine protected areas. Ambio. doi:10.1007/s13280-016-0776-7

Lundmark C, Matti S (2015) Exploring the prospects for deliberative practices as a conflict-reducing and legitimacy-enhancing tool: the case of Swedish carnivore management. Wildl Biol 21:147-156. doi:10.2981/wlb.00009

Luskin R, Fishkin J, McAllister I, Higley J, Ryan P (2000) Information effects in referendum voting: evidence from the australian deliberative poll. Paper presented to the annual meeting of the American Political Science Association, Aug 31-Sept 3

Luskin R, Fishkin J, Jowell R (2002) Considered opinions: deliberative polling in Britain. Br J Polit Sci 32:455-487

Matti S, Sandström A (2013) The defining elements of advocacy coalitions: continuing the search for explanations for coordination and coalition structures. Rev Policy Res 30:240-257. doi:10. 1111/ropr.12011

Meier HEM (2006) Baltic Sea climate in the late twenty-first century: a dynamical downscaling approach using two global models and two emission scenarios. Clim Dyman 27:39-68. doi:10.1007/ s00382-006-0124-x

Murphy JB (2004) Against civic schooling. Soc Philos Policy 21:221-265. doi:10.1017/s0265052504211104

Neumann T (2010) Climate-change effects on the Baltic Sea ecosystem: a model study. J Mar Syst 81:213-224. doi:10. 1016/j.jmarsys.2009.12.001

Parés M, Brugué Q, Espluga J, Miralles J, Ballester A (2015) The strengths and weaknesses of deliberation on river basin management planning: analysing the water framework directive implementation in Catalonia (Spain). Environ Policy Gov 25:97-110. doi:10.1002/eet.1662

Parkins JR, Mitchell RE (2005) Public participation as public debate: a deliberative turn in natural resource management. Soc Nat Resour 18:529-540. doi:10.1080/08941920590947977

Sabatier PA, Jenkins-Smith HC (1999) The advocacy coalition framework: an assessment. In: Sabatier PA (ed) Theories of the policy process. Westview Press, Boulder, pp 117-166

Sandström A (2010) Institutional and substantial uncertainty: explaining the lack of adaptability in fish stocking policy. Mar Policy 34:1357-1365. doi:10.1016/j.marpol.2010.06.009

Sandström A (2011) Navigating a complex policy system: explaining local divergences in Swedish fish stocking policy. Mar Policy 35:419-425. doi:10.1016/j.marpol.2010.11.008

Sandström A, Lundmark C, Jansson E, Edman M, Laikre L (2016) Assessment of management practices regarding genetic biodiversity in Baltic Sea marine protected areas. Biodivers Conserv 25:1187-1205. doi:10.1007/s10531-016-1121-y

Scheerens J, Luyten H, Steen R, Luyten-de Thouars Y (2007) Review and meta-analyses of school and teaching effectiveness. University of Twente

Sevä M (2013) A comparative case study of fish stocking between Sweden and Finland: explaining differences in decision making at the street level. Mar Policy 38:287-292. doi:10.1016/j.marpol. 2012.06.004

Smith G (2001) Taking deliberation seriously: institutional design and green politics. Environ Polit 10:72-93. doi:10.1080/714000562

Sommers CH (2000) The war against boys. How misguided feminism is harming our young men. Simon \& Schuster Paperbacks, New York

Weible CM, Sabatier PA (2005) Comparing policy networks: marine protected areas in California. Policy Stud J 33:181-201. doi:10. 1111/j.1541-0072.2005.00101.x

Weible CM, Sabatier PA (2009) Coalitions, science, and belief change: comparing adversarial and collaborative policy subsystems. Policy Stud J 37:195-212. doi:10.1111/j.1541-0072.2009. 00310.x

Wenk L, Dufresne R, Gerace W, Leonard W, Mestre J (1997) Technology-assisted active learning in large lectures. In: D’Avanzo C, McNichols M (eds) Student-active science: models of innovative in college science teaching. Saunders College Publishing, Philadelphia

Zachrisson A (2010) Deliberative democracy and co-management of natural resources: snowmobile regulation in Western Sweden. Int J Commons 4:273-292. http://hdl.handle.net/10535/5951 